\title{
A SURVEY OF HELMINTH CONTROL PRACTICES IN EQUINE ESTABLISHMENTS IN CZECH REPUBLIC
}

\author{
M. Borkovcová
}

Received: January 21, 2008

\begin{abstract}
BORKOVCOVÁ, M.: A survey of helminth control practices in equine establishments in Czech Republic. Acta univ. agric. et silvic. Mendel. Brun., 2008, LVI, No. 4, pp. 223-230

In year 2006 a survey was done in Czech Republic, in order to gain data about strategy of parasite control and grazing management of horse breeders and owners. 80 questionnaires were evaluated altogether. $82.5 \%$ of breeders claimed self-responsibility for helminth control. All interviewed do the parasite control in all horses at the same time. The results show that in stabled horses the helminth controls are done in interval of 2-4 months. 55\% do the helminth control in April. 91.25\% variegate the medicaments. Most frequently used drug was Panacur. Calculation of needed dose is by $47.5 \%$ respondents done according to the weight of horse. $86.25 \%$ graze horses, $52.2 \%$ change pastures, $53.6 \%$ breeders clean pastures. $32.5 \%$ do the parasite control by examining the excrements, but none of them uses the results to change the strategy of helminth control or grazing management. $72.5 \%$ had never observed any sign of illness of their horses related with parasites, 10\% mentioned skin problems. $70 \%$ respondents call in for a veterinarian when there is a problematic case. $17.5 \%$ breeders encountered resistance and $36.25 \%$ consider the resistance as problem. $72.5 \%$ apply the helminth control according to the veterinarian's advice. 85\% consider their parasite-fighting strategy as suitable.
\end{abstract}

control methods-helminths, horse

After world war two rapid decline of numbers of horses occurred in the Czech Republic connected with the collectivization of countryside. Historians agree on the opinion, that the countryside collectivization was one of the worst communist crimes, which irreversibly stigmatized community, destroyed the farmers' estate, traditional ways of country life and landscape. Total number of horses fell from 450000 to 20000.

Corporate changes in the Czech Republic after the year 1989 affected horse breeding. According to Central horse evidence number of horses registered to the date 31. 12. 2000 was 28 084, at the end of 2005 there were 54956 horses in possession of 20 513 breeders, while 20453 breeders had less than 30 horses. Thus it is obvious, that the number of small owners increased and horse became free time companion (personal communications).

Attention is now focused on the animals" welfare. Breeders are willing to spend fairly big resources on its account. Question is, however, whether these resources are spent rationally and effectively.

One of the topics in view is sphere of endoparasites, while especially small strongyles belong to the main problems in horse breeding. Anthelmintic resistance (AR) occurred to many drugs, more are presumed to occur (LANGROVÁ et al., 2002). Therefore, it is very important to gain information considering the way of using anthelmintics and management practices, so it will be possible to suggest the most suitable option to prevent occurrence of resistance (LENDAL et al., 1998). Studies on the topic of use of anthelmintic were published for example in Ireland (O'MEARA and MULCAHY, 2002) or Denmark (LENDAL et al., 1998; NIELSEN et al., 2006).

There are many factors promoting the occurrence of AR, such as breaching dose, often cure, use of the same drugs for many years or absence of re-curing of new horses in the batch (BJØRN et al., 1991). Pasture management is also important (CHROUST, 2000; 
LLOYD et al., 2000; BORKOVCOVÁ, 2003). The health status of the horses on the part of endoparasitoses in big farms is observed in the long term (LANGROVÁ et al., 2002). In these breeding resistance was detected and actions and strategies to fight parasites including pasture management were taken. These studies, however, do not include full scale of breeding possibilities and strategies of helminth control and pasture management in Czech Republic.

Aim of this work was to find out which strategies of helminth control and pasture management are used in horse breeding in Czech Republic in order to determine risk factors for AR occurrence. We also wanted to discover, what role veterinarians play in establishing these strategies. Other task was to compare attitude of breeders and veterinarians to helminth control in Czech Republic with countries, where horse breeding was not influenced by coun- tryside collectivization. No similar study had been done in Czech Republic so far.

\section{MATERIAL AND METHODS}

In order to carry out objective comparing, questionnaire method by O'MEARA and MULCAHY (2000) vas used. Questions from this questionnaire are below in Tab. I. Total number of questionnaires sent and distributed was 212. Places, where questionnaires were distributed were: International expert meeting in MZLU Brno, 9th International "Horses in Action" Show at Pardubice Racecourse 2006, Competition organized by Czech Jump Cup Association - Belcredi Castle Grand prix and Regional performance testing of mares in Rosice (Czech Republic). Breeders and owners came from different parts of the country.

I: Format of questionnaire given to equine establishments

\begin{tabular}{|c|c|}
\hline Question & Reply options \\
\hline Principal equestrian discipline catered for & $\begin{array}{l}\text { Flat racing, national hunt, show dumping, hunting, } \\
\text { riding club, other }\end{array}$ \\
\hline \multicolumn{2}{|l|}{ Person responsible for helminth control } \\
\hline \multicolumn{2}{|l|}{ Total number of animals } \\
\hline Type of animals & $\begin{array}{l}\text { Brood mares, young stock, stallions, teasers/ } \\
\text { donkeys, pets, competition }\end{array}$ \\
\hline Frequency of helminth control & $\begin{array}{l}\text { 4-6 weeks, 6-8 weeks, 2-6 months, 6-12 months, if } \\
\text { problem }\end{array}$ \\
\hline \multicolumn{2}{|l|}{ Time of year when helminth control is carried out } \\
\hline \multicolumn{2}{|l|}{ Reasons for adopting these procedures } \\
\hline $\begin{array}{l}\text { Is helminth control carried out in all of the animals } \\
\text { at one time }\end{array}$ & Yes, no \\
\hline Are faecal examinations ever carried out & Yes, no \\
\hline \multicolumn{2}{|l|}{ Details of faecal examinations } \\
\hline $\begin{array}{l}\text { Have you ever sought veterinary advice in relation } \\
\text { to parasites }\end{array}$ & Yes, no \\
\hline Have you had any parasite-related ailments & $\begin{array}{l}\text { Diarrhoea, ill-thrift, colic, ocular lesions, skin } \\
\text { lesions, other }\end{array}$ \\
\hline $\begin{array}{l}\text { Have you encountered resistance to anthelmintic } \\
\text { drugs }\end{array}$ & Yes, no \\
\hline Does anthelmintic resistance concern you & Yes, no \\
\hline Do other animals graze on the farm & Yes, no \\
\hline Do you operate pasture rotation/mixed grazing & Yes, no \\
\hline Do you carry out pasture sweeping & Yes, no \\
\hline How do you choose the type of anthelmintic to use & $\begin{array}{l}\text { Brand name, veterinary advice, price, class of drug, } \\
\text { popular opinion }\end{array}$ \\
\hline \multicolumn{2}{|l|}{ Chat drugs are regularly used } \\
\hline Do you rotate the drugs used & Yes, no \\
\hline \multicolumn{2}{|l|}{ How do you calculate the correct dosage } \\
\hline $\begin{array}{l}\text { Do you believe there is any need for modification } \\
\text { of your anthelmintic strategy }\end{array}$ & Yes, no \\
\hline
\end{tabular}


Interviewed persons were noticed, that results of this questionnaire will be published, but their names won't be made public. Each question was evaluated for percentage share.

\section{RESULTS}

\section{Class of establishments responding}

Answers were collected from 80 respondents, i.e. $37.7 \%$ of all interviewed. Among these 80 respondents were representatives of all types of farms, from big concerns to small holders. Average number of horses owned by one breeder was 13.6, maximal number was 130 horses, minimal 1 horse. Horses were used for many purposes, such as flat racing, show dumping, riding club, agrotourism, and other. All breeders stated combination of at least two activities.

\section{Responsibility for helminth control, and usage of anthelmintic drugs}

$82.5 \%$ of interviewed owners stated, that they themselves are responsible for helminth control of their horses. The rest delegate this duty to other employee - grooms or veterinarians (Fig. la). All interviewed breeders stated, that they carry out the helminth control of all their horses at once. Nearly a half of them $-47.5 \%$, say that the drug dose is calculated according to the weight of the horse. $37.5 \%$ use drug dose recommended by the producer's advice (Fig. 1b). 22.5\% respondents do not know how to prescribe the dose, because calculating and administering is done by a veterinarian. $1.25 \%$ (1 breeder) state that the drug dose is calculated according to the age of the horse. Interval between helminth controls was in all cases more than 4 weeks. Most often used interval is between 2 and 6 months - 53.75\%, or 6 12 months - 35\% (Fig. 1c). 88.75\% respondents did not named drugs they used. From the responses it was not possible to evaluate how often the drugs are rotated, and also they did not mentioned, whether, while rotating drugs, they use groups with different active substance.

Most often used drugs are in Fig. 2a. Active substances of mentioned drugs are ivermectin (Equimax), mebendazol (Telmin, Antiverm), moxidectin (Equest), praziquantel (Equimax), noromectin (Noromectin), and fenbendazol (Panacur). Drugs are most often served in April - 55\% and October $52.5 \%$. Duration of drug serving is in Fig. 2 b.

\section{Grazing management and parasite surveillance}

Most of the respondents stated, that horses are pastured (86.25\%), 52.2\% of them use pasture rotation, $20.3 \%$ of breeders pasture horses together with other animals (Fig. 3a). 53.6\% of breeders cleans pastures from faeces, but did not stated how and how often (Fig. 3b). 32.5\% of breeders does the helminth status check using method of faecal egg counts (FECs) (Fig. 3c). Rest of the respondents (67.5\%) never did any control of drug effectiveness by FECs after helminth control, or checked the helminth status before they applied helminth control. Answers were not sufficient to specify whether they did such control at least in case where helminth problem was expected. And even when check of the helminth status was carried out, consequential system of helminth control was not modified.

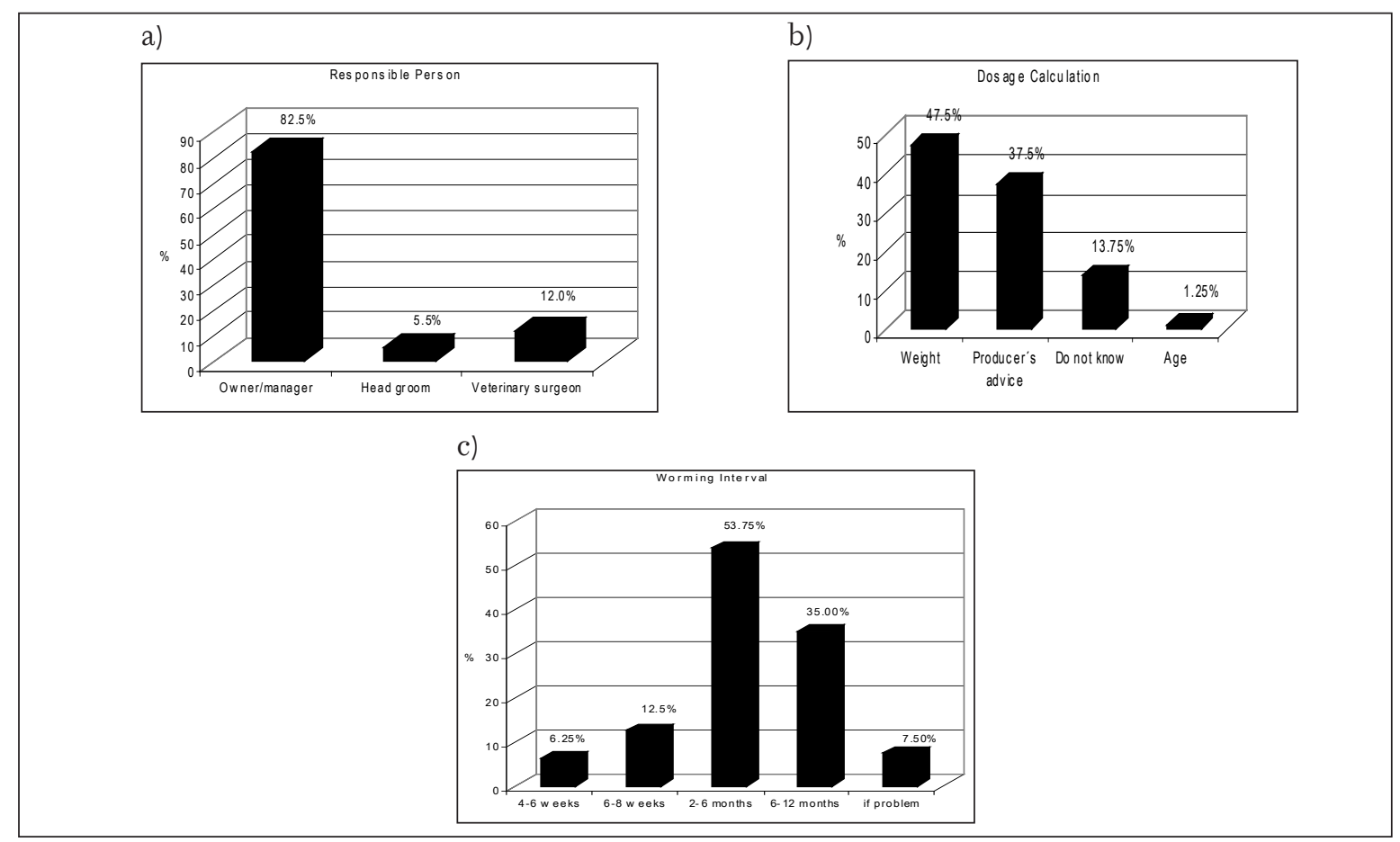

1: Person responsible for parasite control (a), dosage calculation (b), worming interval (c) 


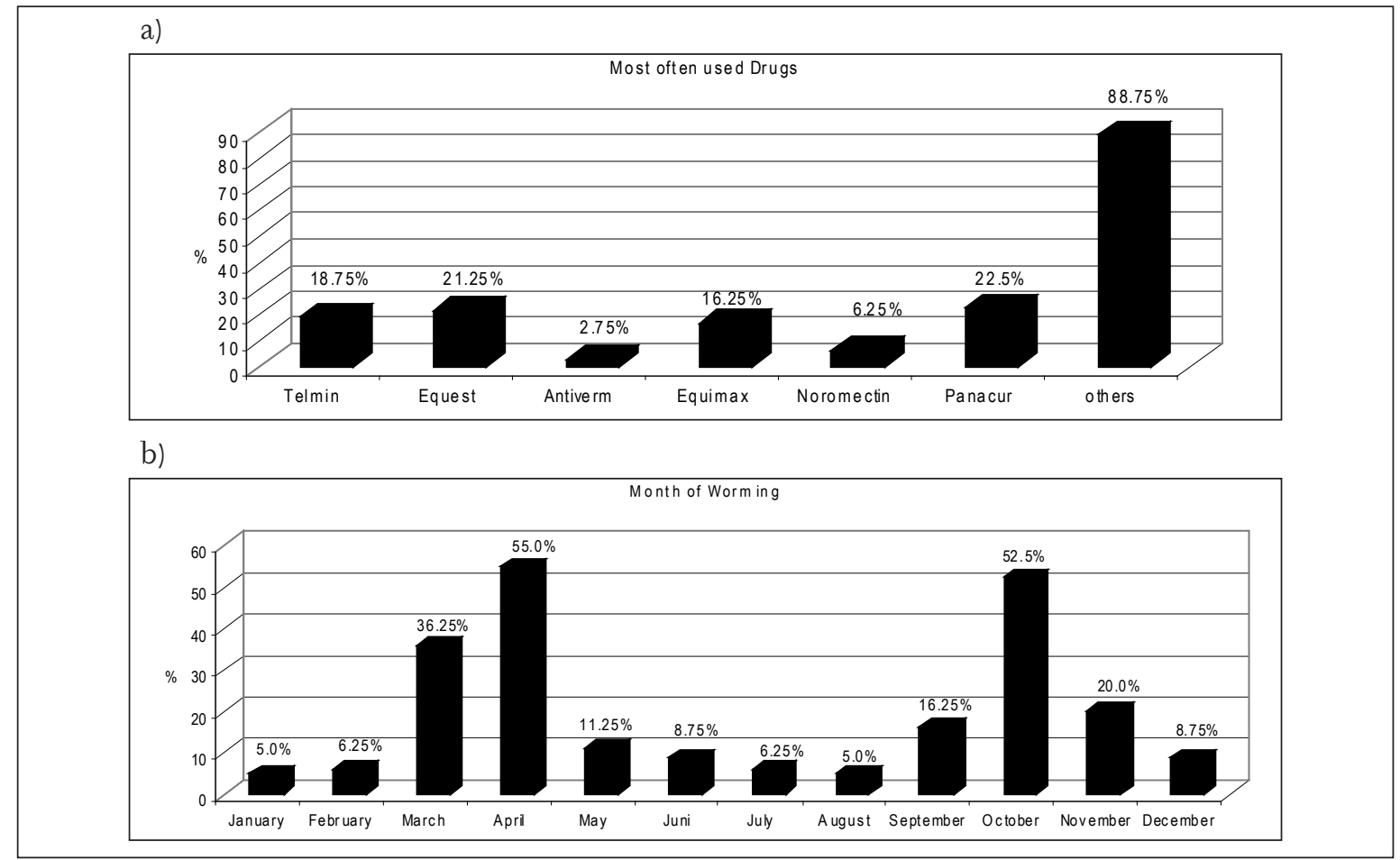

2: Most often used drugs (a), month of worming (b)

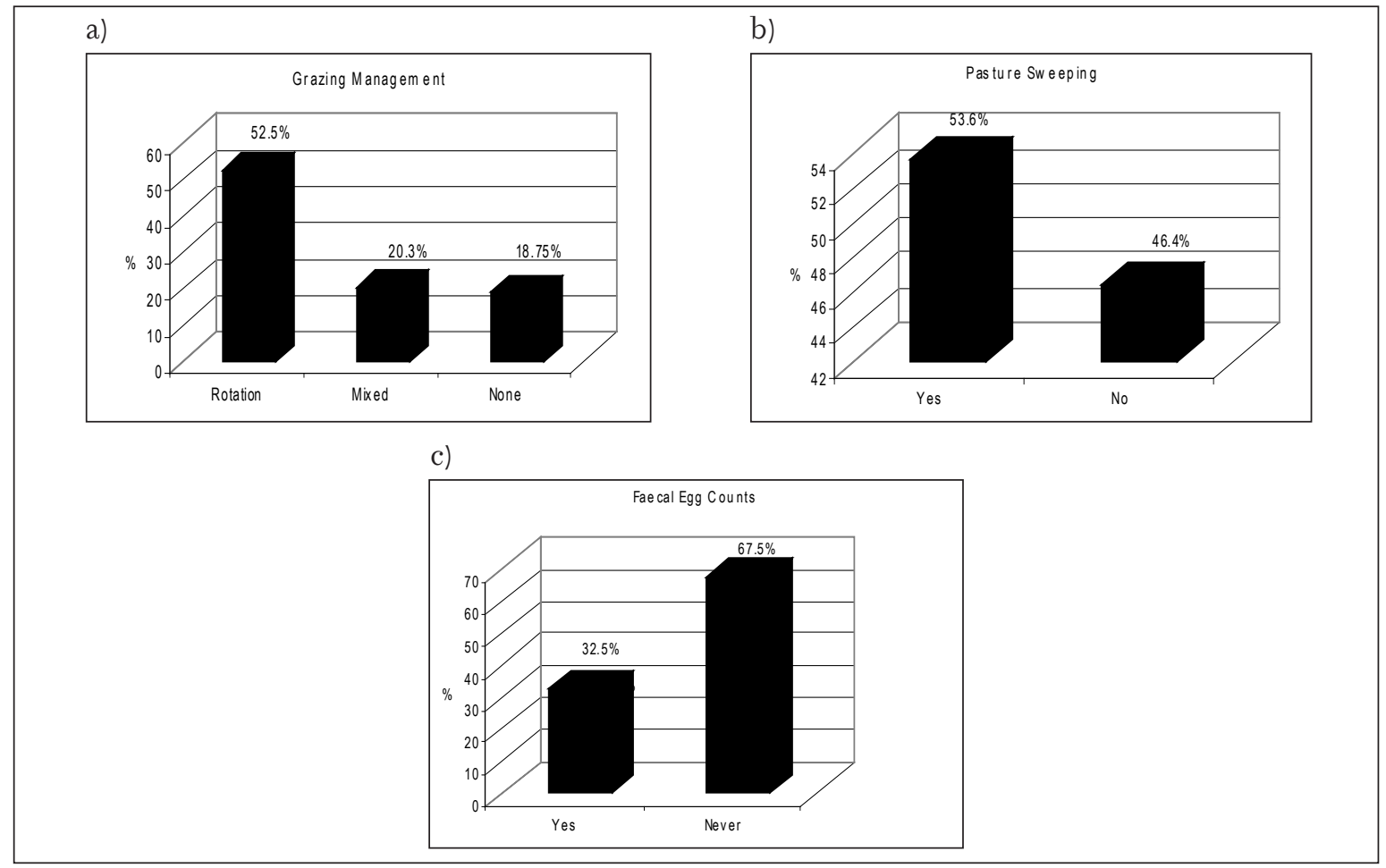

3: Grazing management (a), pasture sweeping (b), faecal egg counts (c)

\section{Health problem attributed to helminth infection}

72.5\% of breeders have not ever noticed any exogenous or endogenous signals or problems, which they would ascribe to parasites. Most often syndromes stated by the rest of breeders are in Fig. 4a. 10\% respondents mentioned skin problems; colic and diarrhoea were both stated by $8.75 \%$. No case of ill-thrift or symptoms co-occurrence was recorded. Most respondents (70\%) call veterinarian, when problematic case occurs (Fig. 4b). 

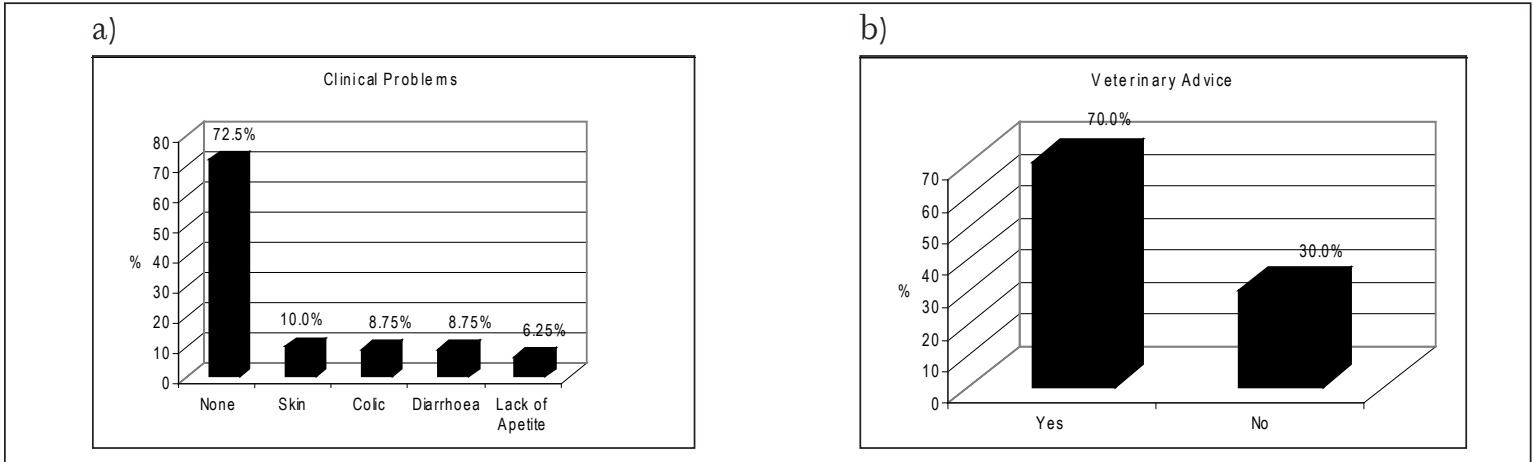

4: Encountered clinical problems (a), sought veterinary advice on parasites (b)

a)

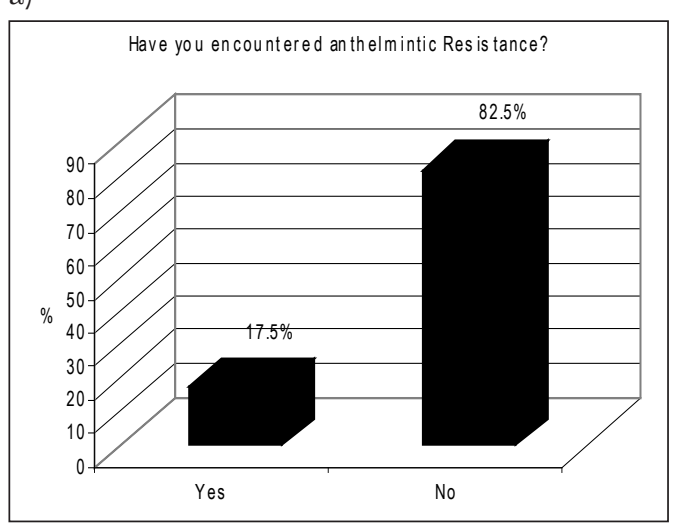

c)

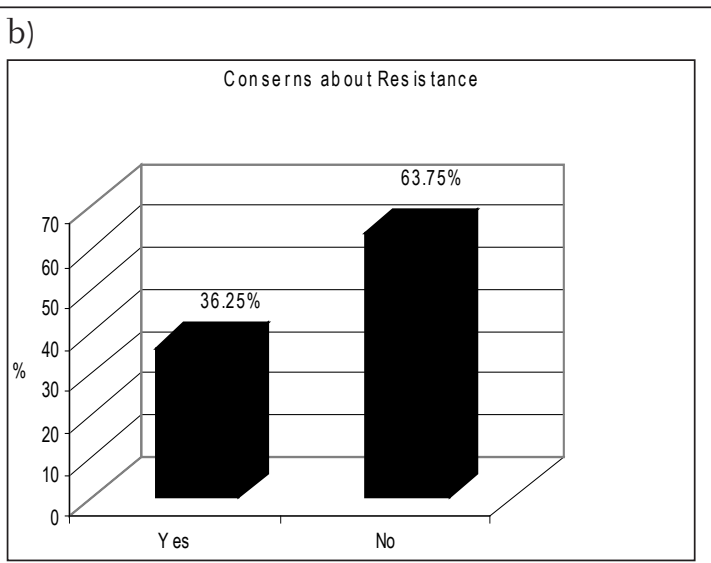

Why this Protocol

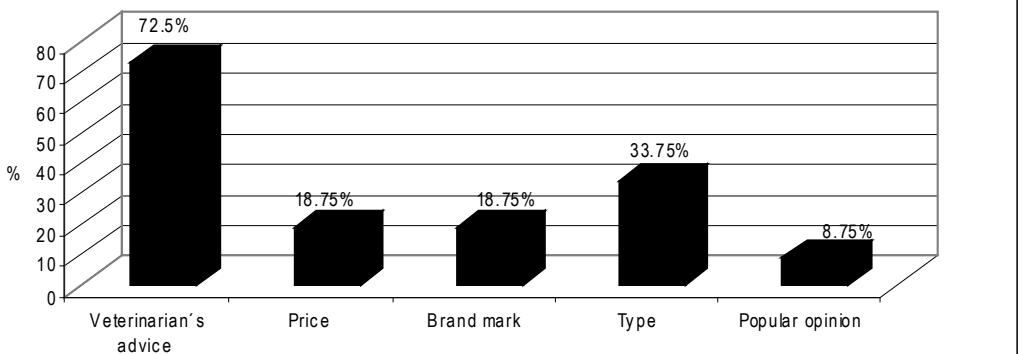

d)

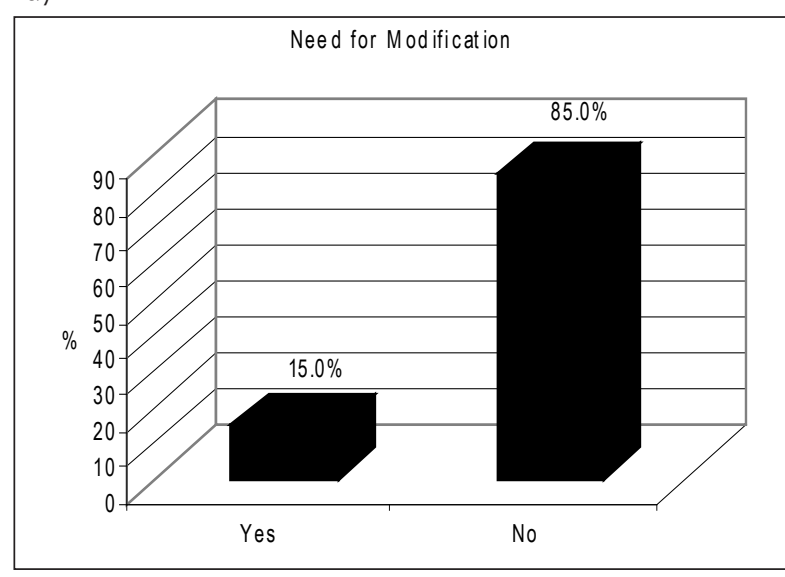

5: Encountered anthelmintic resistance (a), concerns about resistance (b), why respondents used this protocol of helminth control (c), need for modification of this protocol (d) 


\section{Concerns about parasite control programmes}

$17.5 \%$ of interviewed breeders have already encountered parasites ${ }^{6}$ resistance to anthelmints (Fig. 5a). 36.25\% of respondents consider resistance as a problem (Fig. 5b). $85 \%$ of them consider their strategy of helminth control sufficient and only 15\% thinks about change (Fig. 5c). $72.5 \%$ respondents use drugs recommended by veterinarian and quite a great deal of them $-33.75 \%$ make decision according to the type of drugs (Fig. 5d).

\section{DISCUSSION}

We compare the results of our survey with similar survey carried out in Ireland (O'MEARA and MULCAHY, 2002). The match of status and helminth control is stunning, considering the difference of before all the socio-economic development of both countries. Distinctive differences were registered only in few tested items.

It was confirmed, that veterinarians play important role in Czech Republic, but not optimal, according to the parasite-fighting strategies. While in Ireland $54 \%$ of respondents abide by veterinarian's advice (O'MEARA and MULCAHY, 2002), in Czech Republic it is $72.5 \%$. Veterinarians and drug manufacturers both prefer using drugs instead of using other ways of restricting parasitic stress, for example pasture management. Quite logically, their economical interests lead them. Confidence in veterinarians' advices reflects in low number of those, who would like to change their program of helminth control (15\%), while in Ireland it is $22 \%$ respondents (O'MEARA and MULCAHY, 2002).

Responsibility for administering the medicine is usually on the owners (82.5\%), distinctively less on the head grooms (5.5\%). In their survey O'MEARA and MULCAHY (2002) detected $74 \%$ and $16 \%$ respectively. Very significant difference between surveys from other countries is in the interval of helminth control. While in Ireland 38\% respondents use interval of 4-6 weeks (O'MEARA and MULCAHY, 2002), in Denmark it is 97\% (LENDAL et al., 1998). In Czech Republic it is $6.25 \%$. On the contrary, most breeders (53.75\%) in Czech Republic do the helminth control after every 2-6 months, in Ireland it is only $28 \%$ (O'MEARA and MULCAHY, 2002). Concerning the difference between intervals of helminth control it is interesting, that the resistance on certain drugs was detected by the same volume in Czech Republic as in Ireland (17.5\% and 14\% respectively), which can be explained by more suitable drug altering by Ireland owners, which can result from better awareness of this topic (Czech republic 36.25\%, Ireland 61\%). On the other hand lesser awareness of breeders in Czech Republic could theoretically be compensated by more intensive care about pasture grounds, when pasture sweeping is stated by $53.6 \%$ respondents, while in Ireland only $32 \%$ of breeders clean pasture areas (O’MEARA and MULCAHY, 2002).

Quite a big part of breeders uses for helminth control drugs with trademark Telmin (18.75\%) and Pan- acur $(22.5 \%)$, where the active substances are mebendazol and fenbendazol respectively. The reason of growth of detected resistance in breeding can therefore just confirm the results of previous studies (NOVÁKOVÁ and KOUDELA, 2006), that there are strains of parasites, which are resistant to these drugs.

Use of ivermectin spreads, but resistance to it has not been proved in Czech Republic so far (NOVÁKOVÁ and KOUDELA, 2006). Ivermectin has 100\% effectiveness on adult cyathostomes (LENDAL et al., 1998) and Haemonchus contortus in Czech Republic and around the world (CHROUST, 2000). If ivermectin is used sensitively it is highly effective against parasites resistant to benzimidazol (HERD, 1992). According to Danish study (LENDAL et al., 1998) ivermectin was the most commonly used anthelmintic in Danish horse herds.

FECs are very useful method of controlling the parazitological status of animals and also of detecting the effectiveness of helminth control. $67.5 \%$ of respondents interviewed in our study stated, that they have never done any examination before treatment, in other words they do the prophylactic - preventive action, not treatment, as it should be. These breeders do not carry out FECs, even when there is a suspicion of parasitic infection. LENDAL et al. (1998) presents more optimistic data in his study, when $25 \%$ of respondents stated they do the FECs, although $41 \%$ of them did such checkups because of different reason than parazitological. EARLE et al. (2002) claims, that $89 \%$ FECs of all done was undertaken for investigation of suspected parasite problem.

Startling fact is the very short interval of some breeders' helminth control in Ireland- 4-6 weeks (O'MEARA and MULCAHY, 2002), which can have no connection to epidemiology of parasite. But strategic treatment times are prior to pasture rotation (HERD, 1992) so that heavy contamination of pastures can be avoided. Standard practice of Czech Republic is helminth control twice a year, as the veterinarians recommend.

In our survey it was found out, that most respondents do helminth control in April and October, quite high part also in March. These terms are connected to common pasture and co-pasture strategy, commonly practiced in small and larger breeding under the conditions of Czech Republic, when the helminth control of the horses is done before releasing them to the pastures and in autumn before the pasturing season ends.

Question is, why more than a half of breeders did helminth control, when they have never done FECs checkups and their horses have no visible problems. Breeders, who use badly chosen drug and most importantly bad helminth control strategy, can cause high stress to their horses caused by drug side effects while trying to do the best for them, and the parasites problem is not solved either. Total number of the horses in Czech Republic is much lower compared to the number of people. However, human parasitoses are treated individually and only after the 
problems outbreak or by preventive actions aimed on the parasites' live cycle outside the human body. Why not approach horses" parasitoses the same way? More over, horses are not sensitive all the same way, so there is a possibility to use especially these naturally resistant individuals for breeding.

\section{CONCLUSION}

According to results of this survey and their comparing with those of Ireland and Denmark it is obvious, that collectivization did not influence the status of horse endoparasites in Czech Republic distinctively. Attitude of veterinarians and breeders to this issue is basically the same as in Denmark and Ireland. Also no significant differences were detected in the helminth control methods. More important differences were stated in the interval of helminth control. The most hazard factor seems to be the low level of awareness of breeders concerning this topic and consequentional underestimation of this threat. As a result poor attention is paid to all other aspect, above all the alternation of drugs used for helminth control.

\section{SOUHRN}

Dotazníková akce o odčervovacích praktikách v chovech koní v České republice

V roce 2006 byla v České republice provedena dotazníková akce s cílem získat údaje o strategiích odčervování a pastevním managementu chovatelů a majitelů koní. Celkem bylo vyhodnoceno osmdesát dotazníků. 82,5 \% chovatelů tvrdí, že jsou sami zodpovědní za odčervování. Všichni chovatelé provádí odčervení u všech koní zároveň. Výsledky ukázaly, že u ustájených koní je odčervování prováděno v intervalu dvou až čtyř měsíců. 55 \% provádí odčervování v dubnu. 91,25 \% stř̌́dá odčervovací přípravky. Nejčastěji užívaným odčervovadlem je Panacur. Výpočet potřebné dávky provádí 47,5 \% respondentů podle váhy koně. 86,25 \% koně pase, 52,2 \% stř́ídá pastviny, 53,6 \% je čistí. 32,5 \% provádí kontrolu exkrementů na př́ítomnost parazitů, ale žádný z nich nevyužívá výsledky k následné změně odčervovací strategie nebo pastevního managementu. 70 \% respondentů volá v př́padě výskytu komplikací veterináŕe. 17,5\% chovatelů se již setkalo s rezistencí na odčervovadla a 36,25\% považuje tuto rezistenci za problém. 72,5 \% provádí odčervování podle pokynů veterináře. 85 \% je přesvědčeno, že jejich strategie boje s parazity je dostačující. Z výsledků této práce ve srovnání s výsledky v Irsku, Dánsku a v Anglii je zřejmé, že př́stup jak veterinárních lékařŭ, tak chovatelů k problematice endoparazitóz je prakticky shodný ve sledovaných zemích. Rovněž ve způsobech odčervování a pastevním managementu nebyly shledány zásadní odlišnosti. Významnější rozdíly se vyskytly v intervalech odčervení. Jako nejrizikovější faktor pro vznik rezistentních kmenů endoparazitů se jeví především nízká informovanost chovatelů o této problematice a z ní vyplývající podceňování tohoto nebezpečí. Následkem toho je pak věnována malá pozornost všem ostatním aspektům, především pak stř́ídání léčiv.

odčervování, koně

\section{ACKNOWLEDGEMENTS}

Our thanks to all respondents who kindly filled up the questionarries.

\section{REFERENCES}

BJØRN, H., SOMMER, C., SCHOUGAARD, H., HENRIKSEN, S. A. and NANSEN, P., 1991: Resistance to benzimidazole anthelmintics in small strongyles (Cyathostominae) of horses in Denmark. Acta Veterinaria Scandiavica, 32: 253-260. ISSN 0065-1699.

BORKOVCOVÁ, M., 2003: Annual dynamics of gastrointestinal helminths of sheep. Acta universitatis agriculturae et silviculturae Mendelianae Brunensis, 51, 1: 61-67. ISSN 1211-8516.

CHROUST, K., 2000: Occurence of anthelmintic resistance in strongylid nematodes of sheep and horses in the Czech Republic. Veterinary MedicineCzech, 45, 7: 233-239. ISSN 0375-8427.

EARLE, C. G., KINGTON, H. A. and COLES, G. C., 2002: Helminth control used by trainers of tho- roughbreds in England. Veterinary Record, 150: 405-408. ISSN 0042-4900.

HERD, R.P., 1992: Choosing the optimal equine anthelmintic. Veterinary Medicine, 87: 231-239. ISSN 0208-5763.

LENDAL, S., LARSEN, M. M., BJØRN, H., CRAVEN, J., CHRIEL, M. and OLSEN, S. N., 1998: A questionnaire survey on nematode control practices on horse farms in Denmark and the existence of risk factors for the development of anthelmintic resistance. Veterinary Parasitology, 78: 49-63. ISSN 0304-4017.

LLOYD, S., SMITH, J., CONNAN, R. M., HATCHER, M. A., HEDGES, T. R., HUMPHREY, D. D. and JONES, A. C., 2000: Parasite control methods used by horse owners: factors predisposing to the development of anthelmintic resistance in nematodes. Veterinary Record, 146: 487-492. ISSN 0042-4900. 
LANGROVÁ, I., BOROVSKÝ, M., JANKOVSKÁ, I., NAVRÁTIL, J. and SLAVÍK, V., 2002: The benzimidazole resistance of cyathostomes on five horse farms in the Czech Republic. Helminthologia, 39, 211-216. ISSN 0440-6605.

NOVÁKOVÁ, K. and KOUDELA, B., 2006: Occurrence of resistance to anthelmintics in horse breeds in the Moravian Region. Veterinárství, 56: 20-23. ISSN 0506-8231.
NIELSEN, M. K., MONRAD, J. and OLSEN, S. N., 2006: Prescription-only anthelmintics - A questionnaire survey of strategies for surveillance and control of equine strongyles in Denmark. Veterinary Parasitology, 135: 47-55. ISSN 0304-4017.

O’MEARA, B. and MULCAHY, G., 2002: A survey of helminth control practices in equine establishments in Ireland. Veterinary Parasitology, 109: 101-110. ISSN 0304-4017.

Address

Ing. Marie Borkovcová, Ph.D., Ústav zoologie, rybářství, hydrobiologie a včelařství, Mendelova zemědělská a lesnická univerzita v Brně, Zemědělská 1, 61300 Brno, Česká republika, e-mail: borkov@mendelu.cz 